\title{
Spindle Cell Lipoma
}

National Cancer Institute

\section{Source}

National Cancer Institute. Spindle Cell Lipoma. NCI Thesaurus. Code C4254.

A benign circumscribed tumor composed of spindled cells, adipocytes, and collagen

bundles. There is no evidence of nuclear hyperchromasia or mitotic activity. 